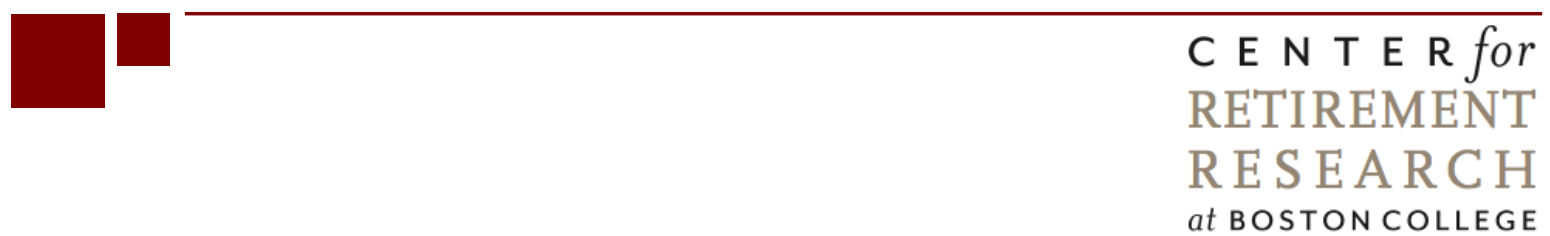

\title{
ECONOMIC CONSEQUENCES OF THE GREAT RECESSION: EVIDENCE FROM THE PANEL STUDY OF INCOME DYNAMICS
}

\author{
Barry Bosworth \\ CRR WP 2012-4 \\ Date Released: February 2012 \\ Date Submitted: January 2012 \\ Center for Retirement Research at Boston College \\ Hovey House \\ 140 Commonwealth Avenue \\ Chestnut Hill, MA 02467 \\ Tel: 617-552-1762 Fax: 617-552-0191 \\ http://crr.bc.edu
}

Barry Bosworth is a senior fellow in economic studies at the Brookings Institution. The research reported here was performed pursuant to a grant from the U.S. Social Security Administration (SSA) funded as part of the Retirement Research Consortium (RRC). The opinions and conclusion expressed are solely those of the author and do not represent the opinions or policy of SSA, any agency of the federal government, the RRC, the Brookings Institution, or Boston College.

(C) 2012, Barry Bosworth. All rights reserved. Short sections of text, not to exceed two paragraphs, may be quoted without explicit permission provided that full credit, including (C) notice, is given to the source. 


\begin{abstract}
About the Center for Retirement Research
The Center for Retirement Research at Boston College, part of a consortium that includes parallel centers at the University of Michigan and the National Bureau of Economic Research, was established in 1998 through a grant from the Social Security Administration. The Center's mission is to produce first-class research and forge a strong link between the academic community and decision-makers in the public and private sectors around an issue of critical importance to the nation's future. To achieve this mission, the Center sponsors a wide variety of research projects, transmits new findings to a broad audience, trains new scholars, and broadens access to valuable data sources.
\end{abstract}

\author{
Center for Retirement Research at Boston College \\ Hovey House \\ 140 Commonwealth Avenue \\ Chestnut Hill, MA 02467 \\ phone: 617-552-1762 fax: 617-552-0191 \\ e-mail: crr@bc.edu \\ crr.bc.edu
}

Affiliated Institutions:

The Brookings Institution

Massachusetts Institute of Technology

Syracuse University

Urban Institute 


\begin{abstract}
The paper uses micro-survey data from successive waves of the Panel Study on Income Dynamics to investigate the distribution of wealth and job losses during the 2007-09 recession for different segments of the population and the effect of the recession on the retirement decisions of older workers. Estimates of wealth losses are constructed for major socioeconomic groups and compared with those of the Survey of Consumer Finances. The panel dimension of the data is used to measure change in the labor force status of workers and to estimate the determinants of the decision to transition from participation in the labor force to retirement. The study concludes that retirement decisions are influenced both by variations in labor market conditions and by the value of household wealth but that labor market exerts a larger impact.
\end{abstract}




\section{Introduction}

The 2007-09 recession was the most severe economic downturn of the post-World War II era. The nation's output (GDP) fell 8 percent below trend between the fourth quarter of 2007 and mid-2009, and the unemployment rate doubled to over 9 percent. On average, households lost one-quarter of their wealth between the middle of 2007 and early 2009, and a third of those losses were in home equity. ${ }^{1}$ The total magnitude of the economic losses can be estimated with some precision from aggregate economic statistics, such as the national accounts and the flow of funds accounts. In the immediate aftermath of the recession, however, we knew much less about the distribution of those losses across the general population. Information from more detailed surveys about changes in the economic circumstance of households is now becoming available.

This paper uses information from the 2009 and earlier waves of the Panel Study on Income Dynamics (PSID) to investigate the distribution of wealth and job losses during the recession for different segments of the population. In the following section, we summarize some of the estimates of wealth and employment change from the survey and compare them to the aggregate measures to evaluate the extent to which the survey captures the general characteristics of the recession. The second section uses the panel dimension of the survey to explore the effects of the recession on patterns of job change. For example, changes in individuals’ economic circumstances are known to influence their retirement decisions. A weakening of the job market, which occurred between 2007 and 2009, encourages workers to retire at an earlier age than they had previously planned. On the other hand, losses of wealth from the associated fall in asset prices might encourage workers to delay retirement. The existence of data on large wealth changes between 2007 and 2009 at the individual household level offers a unique opportunity to evaluate these two offsetting responses.

\section{The Distribution of Wealth Losses}

Three nationally representative surveys provide detailed information on the impacts of the recession on individual households: the Survey of Consumer Finances (SCF), the Health and Retirement Study (HRS), and PSID. The SCF is a triennial survey that focuses on the distribution of wealth and income across households. It normally uses new sample frames for

\footnotetext{
${ }^{1}$ Data are from the quarterly balance sheet for the household sector in the Flow of Funds Accounts. The estimates include nonprofit institutions.
} 
each wave, but a special re-interview was undertaken for the 2007 survey in 2009, which provides a panel dimension. The panel is based on 3,862 households from the original 2007 sample of 4,422 (Kennickell, 2011a). Due to privacy concerns, the micro-survey data from the 2009 re-interview have not yet been publically released, but two Federal Reserve staff articles discussing its major findings are available. The HRS is a biennial longitudinal survey that focuses on individuals aged 50 and over, but the release of the data for 2010 was too late to be included in this study. However, some of the major findings are reported in Gustman, Steinmeier and Tabatabai (2011). ${ }^{2}$ The PSID is a long-standing longitudinal survey, which has been conducted on a biennial schedule since 1999, and the data sets are publically available for both 2007 and 2009, spanning the recession period. It provides extensive information on the wealth, income, employment and other socio-economic characteristics of American families, and it is the major data source for the analysis reported in this paper. ${ }^{3}$

Prior Analysis. The results from the 2007-09 SCF panel are reported in Bricker and others (2011) and Kennickell (2011). Using a broad definition of wealth that includes financial and nonfinancial assets (inclusive of vehicles) less outstanding debts, the mean value of net worth declined by 19 percent and the median fell by 23 percent. The average loss is very close to the aggregate estimate from the flow of funds, although there are some differences in coverage. ${ }^{4}$ One of the most striking findings of the SCF panel is the wide diversity of outcomes across individual households. While most households had losses (62 percent), the median decline was -45 percent, whereas the median gain was 57 percent. Arraying households by the percent of wealth change, the $25^{\text {th }}$ percentile had a 57 percent loss and the $75^{\text {th }}$ percentile reported a gain of 27 percent. A contrasting finding, highlighted in the summary shown in Table 1, was that the magnitudes of median percent change in wealth were very similar across age groups, categories of educational attainment, and 2007 levels of income. The percent loss rose slightly with 2007 wealth and was largest for the self-employed. It was largest in the West where the collapse of

\footnotetext{
${ }^{2}$ See also the earlier discussion in Gustman, Steinmeier and Tabatabai (2010).

${ }^{3}$ Because the questionnaire asks about income in the prior calendar year, the PSID does not have income data beyond 2008 and it does not reflect the extent of the income losses that were concentrated in late 2008 and early 2009.

${ }^{4}$ The flow of funds accounts include defined-benefit retirement accounts, and consumer durables other than vehicles all of which are excluded from the SCF.
} 
home values was most severe and smallest in the Northeast. Nonwhites also had significantly larger percentage losses than whites. The median losses were concentrated in equities (-30 percent), own business (-25 percent), vehicles (-26 percent), and primary residence (-11 percent).

The analysis of wealth changes in the HRS by Gustman, Steinmeier and Tabatabai (2011) covers a longer time period than the SCF, from 2006 to 2010, and they emphasize a broader measure of wealth that includes the expected present value of social security benefits and private defined-benefit pensions. The latter two categories represent nearly half of the reported average wealth. They focus on the age cohort approaching retirement, those households with a member born between 1948 and 1953, also known as the early baby-boom generation (a sample of 1,949 households). They report a much small wealth loss than the SCF for persons of that age, only a three percent fall in wealth, exclusive of Social Security and defined benefit pensions, between 2006 and 2010 (Table 2) compared to about 15 percent in the SCF. They show magnitudes of loss in own business comparable to those for the SCF, and a large decline (-23 percent) in home equity. ${ }^{5}$ The major difference relative to the SCF is a 20 percent increase in the value of equities. In part that difference is due to the longer time period in the HRS analysis. The stock market rose in both 2006-07 and 2009-10 with result that there was a much smaller overall fall in equity values. Another striking finding is that a decline in the broad definition of wealth was limited to the top two deciles of the population. Hence, the authors conclude that the "Great Recession” had a relatively modest impact on the early baby-boomers.

Gustman, Steinmeier and Tabatabai also examined the retirement experience of the early baby-boom generation between 2006 and 2010, and compare it with patterns of retirement for older cohorts in the HRS at comparable stage of their work life. Except for some increase in the proportion not working but not retired, they conclude that the labor market experience of the early boomers was not materially different than that of previous cohorts, and that the recession had only a minor impact on their retirement behavior. Thus, from both the perspective of wealth accumulation and retirement, they conclude that the recession was a minor event for those near retirement.

Other studies have reported on the consequences of the recession at the level of individual households, but few are able to span the full period of the recession. Hurd and

\footnotetext{
${ }^{5}$ The analysis of the SCF focused on home value rather than owner equity; but using median values of own residence and mortgage debt, the fall in home equity within the SCF seem to be of comparable magnitude.
} 
Rohwedder (2010) used data from the RAND American Life Panel, which is an internet-based survey conducted on a monthly basis, to evaluate the effects of the recession on household finances. The panel is useful in tracking on a very current basis the effects on expenditures, home value, and a variety of questions aimed at evaluating the extent of financial distress, but it was initiated after the recession began with the first survey in November of 2008. Chakrabarti and others (2011) also used data from the American Life Panel to argue that the effects of the recession were large but highly variable across households by income, age, and geography, and that the losses were most pronounced for younger households. Again they focus on the period after the onset of the crisis.

Results from the PSID. The analysis makes use of data from the last six waves of the PSID, covering the period of 1999 to 2009. While the interviews for the 2009 wave were undertaken during the months of March through December, over 75 percent of the households were interviewed in April-June. The NBER dates the recession as extending from December of 2007 to June of 2009, thus the 2007 and 2009 waves of the survey span the bulk of the recession period. The earlier waves are included to provide a benchmark for comparison and a data set for later regression analysis.

The Survey distinguishes among eight asset components: (1) home equity, (2) other real estate, (3) private business/farm, (4) vehicles, (5) transaction accounts, (6) corporate equities, (7) annuities/IRAs, and (8) other savings. All of these assets are defined net of any associated debt. In addition, information is collected on a ninth category of non-collateralized debt. While the detail is much less than that of the SCF, the net wealth estimates of the PSID correspond very closely to those of the SCF up to about the $95^{\text {th }}$ percentile of the wealth distribution. As shown in Figure 1, the estimates of average wealth holdings for the lower 95 percent of all households are virtually identical. ${ }^{6}$ The correspondence is much worse above the $95^{\text {th }}$ percentile, however, where the vast bulk of the wealth is concentrated. In recent SCF surveys, over 60 percent of wealth is held by families above the $95^{\text {th }}$ percentile of the distribution. Because those very wealthy households are underrepresented in the PSID, it accounts for only about two-thirds of the total wealth reported in the SCF.

\footnotetext{
${ }^{6}$ The data underlying the figure excludes vehicles because of a concern about the comparability between the SCF and the PSID in the treatment of leased vehicles and those supplied by a business. However, vehicles are included in the later analysis because they are an important component of the wealth of low-income households.
} 
The PSID has been particularly useful for studies of home ownership because of its ability track individual households over long time periods. The data on home value, mortgage debt and net equity extend back to the 1980s, and the quality of the responses seems high. This is illustrated in Figure 2, which shows an index of home price changes constructed from the responses in the PSID, and comparable values from the national price indexes of Standard and Poor's and the Federal Housing Finance Agency (FHFA). The PSID index is computed from the changes in the self-reported home price for households who did not move between two consecutive waves of the survey and they are chained together to form the price index. The correspondence is particularly close with the FHFA index, and the PSID index captures the historical build-up of home prices and an 11 percent fall over the 2007-9 period.

A similar measure of household holdings of corporate equities was computed for comparison with the S\&P stock price index over the five sub-periods from 1999 to 2009. The overall correlation is 70 percent, but the PSID-based measure does not capture the volatility of a large price fall in 2001-03 and rise in 2003-05. Instead, the PSID shows a relative stable level of equity prices over the four years. It indicates a -24 percent drop in the value of equities between 2007 and 2009, compared to -45 percent change in the S\&P index. ${ }^{7}$ The general impression from this overview of the survey responses is that the PSID data do reflect the broad outlines of the historical patterns of change in home prices and the stock market, subject to the qualification that it does not include households at the very top of the wealth distribution.

While the panel dimension of the PSID is its distinguishing feature, there is a large turnover in the households that are included in successive waves: new households enter as spinoffs of existing families and other households exit either temporarily or permanently. For example, 8,289 households were interviewed in the 2007 wave and 8,690 in 2009. Between 2007 and 2009, however, 887 households did not participate in the second interview and 1288 new households were added. The sample is therefore limited to 7,378 households that were present in both the 2007 and 2009 waves. ${ }^{8}$ This restriction is imposed to focus on the dynamics of wealth change in the recession rather than treating the two waves as independent cross

\footnotetext{
${ }^{7}$ The PSID does ask respondents to report net purchases and sales of equities in arriving at a measure of the price change, but the quality of the responses is thought to be low. The computation of the change in the S\&P index assumes a short lag and uses the average of the $1^{\text {st }}$ quarter and the 4th quarter of the prior year.

${ }^{8}$ The number of households that can be matched across successive waves has grown over the years. It was 6,196 in 1999-2001.
} 
sections of the population in the two years. The exclusion of the transitional groups, however, results in a sample that is notably older and wealthier than the total. The sample also excludes households with a change in the designated head, which is indicative of a major change in structure, such as death or divorce.

A variety of statistics could be used to summarize the changes in wealth between two or more waves. For example, many studies rely on the median as the primary measure of the typical value since it reduces the influence of extremes. The conditional median, a variant used in the triennial reports of the SCF, focuses on the proportion of households that have a specific asset and the median holdings of those who do. It is a favored measure in situations where a few households have large holdings-particularly, when more than half of all households report zero holdings of some assets. However, medians are not additive, so the sum of the medians of components may be a poor guide to the median of total wealth. Also, in a comparison between two points in time the medians can represent very different households: it is not a match of like with like. Means are additive for a given population and the change in the means is a meaningful measure of the change for the group over time. Particularly in a panel survey, it is a comparison of like with like. The difference between the mean and the median can also be interpreted as a measure of the skewness of the distribution: if the mean rises more rapidly than the median, it suggests that values rose more rapidly at the top of the distribution.

In the case of the current focus on the change in wealth, there is also considerable appeal to a third statistic, the median change. It can only be computed for a panel because it requires the initial computation of the change in a wealth component for each household in the sample, and those changes are then sorted by size. Thus, the median change emphasized the dynamic element of a panel by comparing the same households at two points in time, and it is relatively insensitive to extreme values. In contrast, the changes in the mean and median make no use of the panel dimension and could be equally-well computed from independent cross sections. The median change was the principal measure used in Bricker and others (2011) for their analysis of the SCF panel. ${ }^{9}$

\footnotetext{
9 The percent change was computed calculated as the difference between 2009 wealth and 2007 wealth divided by the absolute value of 2007 wealth. However, unlike the SCF study, those households with a zero value of 2007 asset values are excluded from the calculation rather than assigned a 2007 value of one dollar. The difference is significant only for some underlying asset categories.
} 
A summary of wealth changes from the 2007-2009 PSID is shown in Table 3. The changes are shown by the three metrics of the percent change in the mean, percent change in the median, and the median percent change. The first three columns, under the general heading of Version A, report the changes in wealth between the 2007 and 2009 waves in prices of 2000. At the aggregate level, the three estimates of the change are very similar, varying only between -12 and -15 percent. The losses are somewhat smaller than the comparable estimates from the SCF, which ranged from -18 to -23 for the three different metrics.

The changes in net worth by selected socio-economic characteristics are shown in the lower portions of the table. The three alternative measures of the percent change display more substantial differences. The overall conclusion is comparable to the results reported for the SCF panel: substantial losses across a wide range of socio-economic groups. However, in individual instances the measures of the change are much more volatile. This is somewhat surprising in view of the larger sample size in the PSID. However, it is consistent with earlier analyses that suggest that the wealth estimates of the PSID are subject substantial measurement error (Bosworth and Smart, 2009). The variability is most marked for percentiles of income and percentiles of wealth, and it is most likely due to the fact that the estimates of income and wealth are subject to significant transitory variation-unlike age, education and region- and they are more likely to include substantial measurement error. They also display the largest differences relative to those of the SCF. For example, the percent change in the mean cannot be meaningfully displayed for the bottom third of the wealth distribution because net worth is negative in 2007. In addition, the change in the mean is positive for the middle third of the distribution, and the change in the median is a large positive for the bottom third.

The importance of the transitory factors can be illustrated by using a more permanent measure of income and wealth in 2007 to sort the observations into thirds. They are shown under the heading of version $\mathrm{B}$. The divisions are recomputed using the average values of wealth and income in the 2005, 2007, and 2009 waves. The use of an average centered on the 2007 value is intended to reduce the role of transitory income and wealth factors in the rankings. However, the individual percentage changes are still based on the change in wealth between 2007 and 2009. The result is large revisions to the changes in the mean and median that bring them much closer 
to the values for the median change. ${ }^{10}$ However, the requirement that the household be included for three successive waves does reduce the sample size by about a thousand, and it substantially alters the estimates for the youngest age group and those with less than a high school education.

Overall, the conclusions are similar to the SCF in that, despite the very wide variations in individual wealth changes, the magnitudes of average wealth loss are analogous across a wide range of different socio-economic categories. However, it also appears that the wealth estimates are more volatile than those of the SCF. While they are not presented in this paper, the components of wealth, except for home equity, seem particularly subject to excessive volatility.

\section{Implications for Retirement}

The magnitude of the recession and the associated wealth loss had the potential to significantly alter retirement decisions. The recession itself greatly increased the number of job losers and reduced the number of job openings, making it much harder to find a new job. The resulting discouraged-worker effects might increase rates of exit from the labor market. Such an option would be most attractive to workers of retirement age. On the other hand, the large wealth losses associated with the recession pull in the opposite direction. The fall in asset prices might induce some workers to delay retirement and others to return to the work force. The Current Population Survey provides a wealth of information on changes in labor force status and retirement over the business cycle (Bosworth and Burtless, 2010). However, there is very little information about the wealth of workers in such surveys, and how they might have been impacted by the fall in asset values, forcing researchers to rely on economy-wide measures. Coile and Levine (2010) combined data from the March CPS, the S\&P stock price index, and data on state unemployment and home prices, and conclude that changes in stock market prices do affect retirement decisions, but that the impact is substantially smaller than the effect of weak labor market conditions. They observed no influence of changes in home prices. Bosworth and Burtless examined data from the monthly CPS and reached similar conclusions. However, the wealth data used in those studies refers to the economy as a whole and could be reflective of a large number of other macroeconomic developments. Goda, Shoven, and Slavov (2011) use an

\footnotetext{
${ }^{10}$ At present, there is no meaningful way of determining whether the variability of the wealth data reflects economic shocks or measurement errors. With release of the SCF panel, it may be possible to use a comparison of the two surveys to infer the relative magnitude of economic shocks versus measurement errors. The SCF has much greater resources with which to edit the survey data and correct for some forms of reporting error.
} 
analysis of the 2006 and 2008 waves of the HRS to argue that the stock market decline led to an increase in the expected date of retirement, more than offsetting the effects of a worsening labor market.

The availability of panel data from the PSID provides a unique opportunity to combine information on changes in employment status and the household's wealth holding between the beginning of the recession in 2007 and the trough in mid-2009 to determine their impact on retirement decisions. We use the PSID over the six waves from 1999 to 2009 to examine decisions to retire within a framework that incorporates knowledge of both household wealth and local labor market conditions.

The basic trends in labor force participation of older workers (age 55-69) are shown in the top panel of Figure 3 for the period of 1980- to 2011. For older men, there had been a longstanding historical trend of declining rates of participation as the spread of public and private pensions made retirement a viable option. But that trend reversed in the mid-1990s for reasons that are believed to be related to longer life expectancies and changed incentives within the Social Security system that encourage workers to remain in the labor force as late as age 70. It contrasts with a continuing fall in the participation rate for younger workers (lower panel) that reflects in part the greater utilization of the disability program. However, the rate of increase has slowed since 2005, and it shows a modest drop since the onset of the recession.

There has been a much stronger and continuing upward trend in the labor force participation rate of older women, which is usually attributed to the large changes in the role of women in the economy and society in general. However, while the participation rate of younger women peaked in 2000, the participation rate continued to rise for women aged 55-70 until 2011 when it registered a small decline. The small fall in the participation rates for both men and women since the recession suggests that the "discouraged worker" effects of the recession have exceeded the impact of reduced wealth. However, the household level data of the PSID allows a more detailed exploration of the issue.

Labor Market Transitions. Labor market flows between the five waves of the PSID stretching from 1999 to 2009 are shown in Table 4. Each line focuses on heads of households and spouses who participated in two consecutive waves of the survey and were in the labor force 
in the first period. ${ }^{11}$ In each wave the household respondent is asked about the current employment status of the head and spouse, distinguishing among: employed, unemployed, retired, disabled or out of the labor force for other reasons. For those individuals who were in the workforce (employed or looking for work) in the first wave, the table shows their status in year 3 (the second wave). In addition, the table distinguishes between men and women and those who are above and below age 55, where the probabilities of retirement begin to change substantially.

For women below the age of 55, the proportion that was employed fell sharply between 2007 and 2009, but most remained in the workforce $(84.0+6.5$ percent $)$. About nine percent exited the labor force in year 3 , and that proportion is above the average of the three prior subperiods, which were generally years of strong employment growth. It is not as high as the proportion that exited in 1999-01, another period of recession. Most choose to exit for reasons other than retirement or disability. Men below the age of 55 had a significantly lower probability of labor force exit in the third year-four versus nine percent. Again, the proportion exiting in 2007-09 is higher than in the earlier periods, but the difference is only about one percentage point. Overall, there is some increase in the probability of labor force exit in the recessions of 2001 and 2009, but the observed magnitudes seem very small for both men and women.

The changes in labor force status are quite different for individuals age 55 and over, as shown in the bottom portion of the table. The proportion exiting the labor force in year 3 is substantially larger, and it appears to show greater sensitivity to the business cycle for both men and women. For women over the age of 55, the rate of exit in year 3 averages 20 percent over the past decade and more than two-thirds was due to retirement. The exit rate and the rate of retirement both jumped in the recessions of 2001 and 2009. There is also a jump in the proportion that left the labor force for reasons other than retirement or disability, but it remains well below that of younger women. There is an even larger rise in the exit rate for men over age 55 , and it is more than accounted for by increased retirement. Again, there is evidence of a large cyclical response. In comparing the change for men who were in the workforce in 2007 with the comparable group in 2005, there was a 10 percentage point reduction in the employment rate in

\footnotetext{
${ }^{11}$ The employed and unemployed in year 1 are combined because of the small number of observations on the unemployed. Similarly, it is possible to report on those who were out of the labor force in year 1, but only a small number $(\approx 5$ percent) transition back into the workforce in year 3 . Individual workers are limited to heads of households and spouses to provide a match with household wealth.
} 
year 3, more than a doubling of the number transitioning into unemployment (4.5 versus 1.4 ) and a 7 percentage point rise in the proportion that left the workforce.

The data of Table 4 suggest there was a sharp increase in the rate of retirement of in 2009, and it is at least suggestive that discouraged worker effects, related to conditions in the labor market, dominated the delaying effect of large wealth losses. In addition, the behavior of workers approaching retirement ages seems quite different from that of younger workers.

Determinants of Retirement. A probit model is used to explore further the determinants of workers' decision to retire. The data are restricted to individuals who were in the labor force in the first wave, as with the above transitions, but the individuals' ages are limited to 55-69 to provide a reasonably homogeneous group of potential retirees-a sample size of 4,590 cases. The binary outcome variable is defined as 1 if the respondent is retired in year 3 , and 0 for all other transition states. The prediction model includes indicator variables reflecting each respondent's age in 5-year categories, educational attainment, marital status, whether they have a working spouse, and a measure of their permanent income (defined as the average of household income in the three survey waves corresponding to $\mathrm{t}=0, \mathrm{t}+2$ and $\mathrm{t}-2$ ). In addition, the specification includes the unemployment rate in the respondent's state in year 3 as the measure of labor market conditions. Finally, the regressions include the ratio of household wealth to permanent income in the initial and terminal waves. Alternative specifications of the wealth change add the change in home equity.

The basic regression results are shown in Table 5. The combined sample of men and women is reported in column (1), and separate regressions for men and women are reported in columns (2) and (3). The coefficients on the indicator variables are shown at the top of the table. Married individuals tend to retire earlier than those who are single, but a working spouse reduces the probability of retirement. Household wealth is scaled by the previously-discussed measure of permanent income, and the coefficients on wealth in the terminal and initial years are both positive, suggesting that the large wealth losses in 2009 would have induced individual to continue working and delay retirement. However, only the coefficient on current wealth is statistically significant in the combined regression and wealth is insignificant in the regression for men. More important, the effect of wealth is much weaker than that of labor market conditions. For ease of interpretation, the regressions include a standard national measure of the 
unemployment rate for workers aged 25-54 in the first half of each survey year. That is combined with the differential of the state unemployment rate over the national rate. There is a strong positive effect of national-level unemployment on retirement, but there is also an important influence of unemployment at the state level. Both the wealth and labor market effects are more significant for women than for men. Finally, the fourth regression reports the results of separating household wealth between home equity and other wealth. The coefficients current and lagged home equity are positive; suggesting that the collapse of the housing bubble did induce some households to postpone retirement by more than would have been expected from the overall wealth loss alone. The effect of variations in home equity is larger than for other forms of wealth, but only the coefficient on lagged home equity displays much statistical significance. Because the magnitude of the wealth holdings is correlated between the initial and terminal years, we also performed a joint test of the statistical significant of wealth in both periods. The result is some increase in statistical significance, but wealth still has an insignificant role in the determination of retirement by older men.

The results differ is some respects from the prior research. In contrast to Bosworth and Burtless (2010), which relied on data from the CPS, this analysis of the PSID finds statisticallysignificant evidence that weak labor market conditions accelerate the transition of older women into retirement. The earlier study limited the effect of weak labor market conditions on labor force withdrawal to older men. The overall effects of variations in the unemployment rate on retirement decisions are more substantial in this study. Both studies concur in finding a weak positive effect of wealth on labor force withdrawal, but this analysis also finds a statistically significant impact of variations in home values. The results are more similar to Coile and Levine (2009), but differ in finding an influence of changing home values.

\section{Conclusion}

Our examination of the wealth and employment data from the PSID suggests that the survey captured the major elements of the 2007-09 recession. There are large reported wealth losses that are shared across a broad range of socio-economic groups. The magnitude and widespread nature of the wealth losses generally corresponds with the findings of the SCF. Second, we find a large rise in the rate of transition out of the labor force into retirement in 200709 for older workers. In contrast, younger workers tended to remain in the workforce and a larger 
portion of the decline in employment was absorbed by increased unemployment. Thus, the decline in the labor force participation rate was largely accounted for by the response of older workers. Third, the more formal analysis of retirement decisions over the 1999-2009 period suggests that retirement decisions were influenced both by variations in household wealth and labor market conditions, but that the labor market was the more important determinant. 


\section{References}

Bricker, Jesse, Brian K. Bucks, Arthur Kennickell, Traci L. Mach and Kevin Moore. 2011.

"Drowning or Weathering the Storm? Changes in Family Finances from 2007 to 2009," Board of Governors of the Federal Reserve, Finance and Economics Discussion Series No. 2011-17.

Bosworth, Barry and Gary Burtless. 2010. "Recessions, Wealth Destruction and the Timing of Retirement. Center for Retirement Research at Boston College. Working Paper 2010-22 (Revised October 2011).

Bosworth, Barry, and Rosanna Smart. 2009. “Evaluating Micro-Survey Estimates of Saving and Wealth, Working Paper 2009-4, Center for Retirement Research, Boston College.

Coile, Courtney and Phillip B. Levine. 2009. “The Market Crash and Mass Layoffs: How the Current Economic Crisis May Affect Retirement,” NBER Working Paper 15395.

Chakrabarti, Rajashri, Donghoon Lee, Wilbert van der Klaauw, and Basit Zafar. 2011.

“Household Debt and Saving During the 2007 Recession,” NBER Working Paper 16999.

Goda, Gopi Shah, John B. Shoven and Sita Nataraj Slavov. 2011. "What Explains Changes in Retirement Plans during the Great Recession?” American Economic Review Papers and Proceedings 101(3): 29-34.

Gustman, Alan L., Thomas L. Steinmeier and Nahid Tabatabai. 2010. "What the Stock Market Decline Means for the Financial Security and Retirement Choices of the Near-Retirement Population”. Journal of Economic Perspectives (Winter), vol 24, No. 1: 161-82.

Gustman, Alan L., Thomas L. Steinmeier and Nahid Tabatabai. 2011. "How Did the Recession of 2007-2009 Affect the Wealth and Retirement of the Near Retirement Age Population in the Health and Retirement Study?” University of Michigan Research Retirement Center, Working Paper 2011-253.

Hurd, Michael D. and Susann Rohwedder. 2010. "Effects of the Financial Crisis and Great Recession on American Households". NBER Working Paper 16407. 
Kennickell, Arthur. 2011a. “Look Again: Editing and Imputation of SCF Panel Data,” Board of Governors of the Federal Reserve, Prepared for the 2011 Joint Statistical Meeting, Miami, Florida (August 3).

Kennickell, Arthur. 2011b. “Tossed and Turned: Wealth Dynamics of U.S. Households 20072009,” Board of Governors of the Federal Reserve, Finance and Economics Discussion Series No. 2011-51. 
Table 1. Survey of Consumer Finances, 2007-09, Family Net Worth by Selected Characteristics

Thousands of 2009 dollars except as noted

\begin{tabular}{|c|c|c|c|c|}
\hline \multirow[t]{2}{*}{ Family characteristic } & \multicolumn{2}{|c|}{$\begin{array}{l}\text { Median net } \\
\text { worth }\end{array}$} & \multirow{2}{*}{$\begin{array}{l}\text { Median dollar } \\
\text { change }\end{array}$} & \multirow{2}{*}{$\begin{array}{l}\text { Median } \\
\text { percent } \\
\text { change }\end{array}$} \\
\hline & 2007 & 2009 & & \\
\hline All families & 125.4 & 96.0 & -11.4 & -18.1 \\
\hline \multicolumn{5}{|l|}{ Percentile of income (2007) } \\
\hline Less than 20 & 10.1 & 7.2 & -2.6 & -18.3 \\
\hline 20-39.9 & 39.1 & 32.9 & -4.7 & -15.7 \\
\hline $40-59.9$ & 95.4 & 72.6 & -11.5 & -20.6 \\
\hline 60-79.9 & 216.7 & 167.5 & -32.2 & -18.5 \\
\hline 80-89.9 & 373.5 & 302.5 & -60.4 & -18.5 \\
\hline 90-100 & $1,205.1$ & 894.5 & -168.4 & -18.2 \\
\hline \multicolumn{5}{|l|}{ Age of head (2007) } \\
\hline Less than 35 & 14.2 & 9.0 & -4.9 & -25.5 \\
\hline 35-44 & 97.1 & 69.4 & -6.8 & -19.5 \\
\hline $45-54$ & 203.0 & 150.4 & -23.9 & -19.6 \\
\hline $55-64$ & 257.7 & 222.3 & -13.7 & -15.2 \\
\hline $65-74$ & 232.7 & 205.5 & -18.2 & -13.9 \\
\hline 75 or more & 228.9 & 191.0 & -20.4 & -20.4 \\
\hline \multicolumn{5}{|l|}{ Education of head (2007) } \\
\hline No high school diploma & 34.4 & 21.2 & -3.5 & -18.8 \\
\hline High school diploma & 80.9 & 64.2 & -8.4 & -18.8 \\
\hline Some college & 81.3 & 66.8 & -9.6 & -19.0 \\
\hline College degree & 294.6 & 244.0 & -34.1 & -16.9 \\
\hline \multicolumn{5}{|c|}{ Race or ethnicity of respondent (2007) } \\
\hline White non-Hispanic & 178.8 & 149.9 & -15.4 & -17.0 \\
\hline Nonwhite or Hispanic & 32.8 & 23.3 & -5.6 & -23.7 \\
\hline \multicolumn{5}{|l|}{ Region (2007) } \\
\hline Northeast & 168.9 & 141.4 & -4.9 & -9.5 \\
\hline Midwest & 121.0 & 92.2 & -11.1 & -17.5 \\
\hline South & 102.7 & 83.5 & -10.5 & -17.7 \\
\hline West & 151.0 & 103.2 & -23.3 & -27.7 \\
\hline \multicolumn{5}{|l|}{ Housing status (2007) } \\
\hline Owner & 244.8 & 192.6 & -35.9 & -19.0 \\
\hline Renter or other & 5.5 & 3.6 & -0.4 & -8.7 \\
\hline \multicolumn{5}{|l|}{ Percentile of wealth (2007) } \\
\hline Less than 25 & 1.7 & 1.0 & 0.0 & 0.0 \\
\hline 25-49.9 & 61.3 & 47.7 & -10.7 & -18.1 \\
\hline 50-74.9 & 237.5 & 187.8 & -40.1 & -17.2 \\
\hline 75-89.9 & 616.0 & 465.0 & -134.1 & -21.6 \\
\hline 90-100 & $2,039.2$ & $1,569.0$ & -449.3 & -23.8 \\
\hline
\end{tabular}

Source: Bricker and others (2011). Sample size of 3,673 households. All results are weighted. 
Table 2. Distribution of Wealth, Early Baby Boomers, 2006 and 2010

mean values, thousands of dollars

\begin{tabular}{|c|c|c|c|c|c|}
\hline \multirow[b]{2}{*}{ Source of Wealth } & \multicolumn{2}{|c|}{2006} & \multicolumn{2}{|c|}{2010} & \multirow[b]{2}{*}{$\begin{array}{l}\text { Percent } \\
\text { change }\end{array}$} \\
\hline & $\begin{array}{l}\text { Dollar } \\
\text { value }\end{array}$ & $\begin{array}{l}\text { Percent } \\
\text { of total }\end{array}$ & $\begin{array}{l}\text { Dollar } \\
\text { value }\end{array}$ & $\begin{array}{l}\text { Percent } \\
\text { of total }\end{array}$ & \\
\hline Total & 871 & 100 & 847 & 100 & -2.8 \\
\hline Social Security & 256 & 29 & 256 & 30 & 0.0 \\
\hline Pension Value & 220 & 25 & 218 & 26 & -0.9 \\
\hline Defined benefit & 150 & 17 & 141 & 17 & -6.0 \\
\hline Defined contribution & 70 & 8 & 77 & 9 & 10.0 \\
\hline \multicolumn{6}{|c|}{$\begin{array}{l}\text { Market Wealth (total less social } \\
\text { security and defined-benefit }\end{array}$} \\
\hline pension) & 465 & 53 & 450 & 53 & -3.2 \\
\hline Net House Value & 167 & 19 & 128 & 15 & -23.4 \\
\hline Real Estate & 35 & 4 & 26 & 3 & -25.7 \\
\hline Business Assets & 38 & 4 & 31 & 4 & -18.4 \\
\hline Net Value of Vehicles & 20 & 2 & 17 & 2 & -15.0 \\
\hline Financial Assets & 78 & 9 & 84 & 10 & 7.7 \\
\hline Direct Stock Holdings & 38 & 4 & 42 & 5 & 10.5 \\
\hline IRA Assets & 58 & 7 & 87 & 10 & 50.0 \\
\hline Observations & 1949 & & & & \\
\hline
\end{tabular}

Source: Gustman, Steinmeier and Tabatabai (2011), table 1. Health and Retirement Study. Households with at least one member born in 1948 -1953. Weighted 
Table 3. Changes in Total Wealth by Characteristic of Head, 2007-2009

\begin{tabular}{|c|c|c|c|c|c|c|}
\hline \multirow[b]{2}{*}{ Characteristics } & \multicolumn{3}{|c|}{ Version A } & \multicolumn{3}{|c|}{ Version B } \\
\hline & $\begin{array}{c}\text { Change } \\
\text { in } \\
\text { Means }\end{array}$ & $\begin{array}{l}\text { Change } \\
\text { in } \\
\text { Medians }\end{array}$ & $\begin{array}{l}\text { Median } \\
\text { Change }\end{array}$ & $\begin{array}{l}\text { Change } \\
\text { in } \\
\text { Means }\end{array}$ & $\begin{array}{l}\text { Change } \\
\text { in } \\
\text { Medians }\end{array}$ & $\begin{array}{l}\text { Median } \\
\text { Change }\end{array}$ \\
\hline All families & -13.4 & -15.3 & -12.1 & -13.1 & -16.8 & -12.2 \\
\hline \multicolumn{7}{|c|}{ Percentile of income in 2007} \\
\hline bottom third & -16.4 & 3.6 & -8.6 & -14.6 & -2.1 & -10.2 \\
\hline middle third & -2.5 & -14.1 & -12.1 & -9.4 & -15.6 & -13.0 \\
\hline top third & -15.8 & -16.4 & -15.1 & -13.9 & -14.3 & -13.8 \\
\hline \multicolumn{7}{|l|}{ Age of head in 2007} \\
\hline Less than 35 & -7.6 & 6.9 & 2.3 & -4.3 & -0.2 & 2.3 \\
\hline 35-49 & -21.1 & -29.9 & -17.7 & -20.1 & -26.6 & -17.1 \\
\hline $50-64$ & -7.5 & -15.0 & -12.1 & -7.6 & -13.2 & -12.1 \\
\hline $65+$ & -17.2 & -12.5 & -13.4 & -17.1 & -12.5 & -13.3 \\
\hline \multicolumn{7}{|l|}{ Education of head in 2007} \\
\hline No high school diploma & -11.0 & -3.6 & -11.9 & -10.3 & -13.8 & -11.6 \\
\hline High school diploma & -14.8 & -16.5 & -15.1 & -14.2 & -17.4 & -15.1 \\
\hline Some college & -8.7 & -15.1 & -11.5 & -8.9 & -16.4 & -11.3 \\
\hline College degree & -13.5 & -15.8 & -10.1 & -13.0 & -12.2 & -10.1 \\
\hline \multicolumn{7}{|l|}{ Region } \\
\hline Northeast & -10.6 & -11.7 & -6.9 & -10.0 & -7.9 & -6.6 \\
\hline Midwest & -14.2 & -11.3 & -15.3 & -13.8 & -11.9 & -15.6 \\
\hline South & -6.5 & -11.0 & -8.7 & -6.5 & -10.9 & -8.3 \\
\hline West & -22.6 & -34.8 & -18.8 & -22.7 & -35.0 & -18.8 \\
\hline \multicolumn{7}{|c|}{ Percentile of wealth in 2007} \\
\hline bottom third & n.a. & 42.2 & 25.9 & n.a. & -30.9 & -6.0 \\
\hline middle third & 38.6 & -14.0 & -12.3 & -15.3 & -13.2 & -12.1 \\
\hline top third & -19.3 & -20.5 & -19.7 & -12.6 & -14.2 & -14.2 \\
\hline
\end{tabular}

Sources: Author's calculations from the PSID for 2005, 2007, and 2009.

Version A reports percentage changes based on values in the 2007 and 2009 surveys, and the characteristics are based on 2007 values. Version B uses percentage changes from the 2007- 2009 surveys, but the distributions of income and wealth are based on averages of values for 2005, 2007, and 2009s. The use of an average from three surveys causes a small reduction on the number of observations. Data are computed in prices of 2000. 
Table 4. Changes of Employment Status in the PSID Between Survey Years

Individuals in the Labor Force in Year 1

\begin{tabular}{|c|c|c|c|c|c|c|}
\hline \multirow{3}{*}{ Panel Year } & \multicolumn{6}{|c|}{ Status in year 3 (percent) } \\
\hline & \multirow[b]{2}{*}{ Employed } & \multirow[b]{2}{*}{ Unemployed } & \multicolumn{4}{|c|}{ Not in Labor Force } \\
\hline & & & Total & Retired & Disabled & Other \\
\hline & \multicolumn{6}{|c|}{ Under Age 55 - Female } \\
\hline 1999-01 & 86.7 & 3.2 & 10.1 & 1.2 & 0.9 & 8.0 \\
\hline 2001-03 & 87.2 & 5.0 & 7.8 & 0.7 & 0.7 & 6.4 \\
\hline 2003-05 & 87.1 & 3.7 & 9.2 & 0.7 & 0.6 & 7.9 \\
\hline 2005-07 & 87.7 & 3.9 & 8.4 & 0.4 & 1.2 & 6.8 \\
\hline \multirow[t]{2}{*}{ 2007-09 } & 84.0 & 6.5 & 9.4 & 0.7 & 1.1 & 7.6 \\
\hline & \multicolumn{6}{|c|}{ Under Age 55 - Male } \\
\hline 1999-01 & 92.4 & 4.3 & 3.4 & 1.0 & 0.8 & 1.6 \\
\hline 2001-03 & 92.5 & 4.5 & 3.1 & 0.5 & 1.2 & 1.4 \\
\hline 2003-05 & 93.9 & 3.0 & 3.1 & 0.6 & 1.8 & 0.8 \\
\hline 2005-07 & 92.5 & 4.6 & 2.9 & 0.8 & 0.9 & 1.2 \\
\hline \multirow[t]{2}{*}{ 2007-09 } & 87.0 & 8.9 & 4.1 & 0.9 & 1.0 & 2.2 \\
\hline & \multicolumn{6}{|c|}{ Age 55 and Over - Female } \\
\hline 1999-01 & 74.9 & 2.8 & 22.4 & 17.5 & 0.6 & 4.3 \\
\hline 2001-03 & 79.4 & 1.3 & 19.3 & 13.3 & 0.9 & 5.1 \\
\hline 2003-05 & 80.3 & 2.6 & 17.2 & 11.3 & 2.0 & 3.9 \\
\hline 2005-07 & 80.1 & 1.8 & 18.0 & 13.2 & 0.6 & 4.2 \\
\hline \multirow[t]{2}{*}{ 2007-09 } & 72.1 & 3.3 & 24.6 & 18.5 & 1.0 & 5.2 \\
\hline & \multicolumn{6}{|c|}{ Age 55 and Over - Male } \\
\hline 1999-01 & 74.0 & 0.8 & 25.3 & 24.3 & 0.4 & 0.6 \\
\hline 2001-03 & 83.2 & 1.2 & 15.7 & 14.0 & 1.6 & 0.0 \\
\hline 2003-05 & 87.8 & 0.2 & 12.0 & 10.2 & 1.5 & 0.3 \\
\hline $2005-07$ & 81.8 & 1.4 & 16.8 & 14.8 & 1.4 & 0.6 \\
\hline 2007-09 & 71.7 & 4.5 & 23.7 & 22.0 & 1.0 & 0.7 \\
\hline
\end{tabular}

Source: Computed from successive waves of the PSID for heads of households and spouses, 1999-2009. Labor force status is reported in the second year for individuals who were in the labor force in the first year. The sample size varies between 7,608 in 1999-01 and 9,152 in 2007-09. 
Table 5. Probability of Retiring, Labor Force Participants, Ages 55-70

Individuals in the Labor Force, 1999-2009

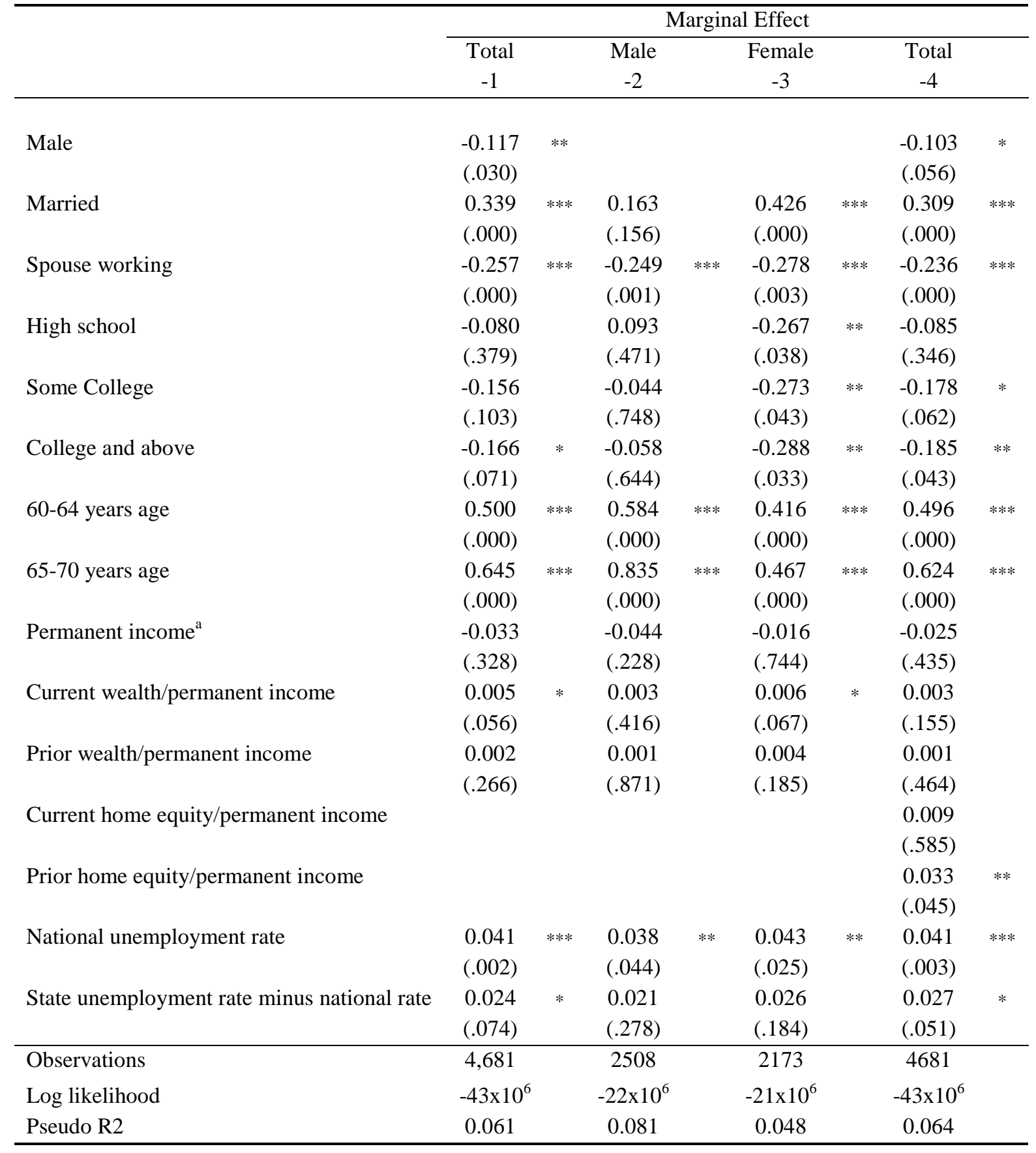

Sources: Author's estimates and data from the PSID, 1999-2009. Probit regression reporting transition from in the labor force to retirement. P-values are in parentheses. Asterisks are used to highlight levels of significance for p-values below $.1, .05$, and .01 respectively.

a. Coefficient on permanent income scaled by100,000. 
Figure 1. Mean Household Wealth by Uniform SCF Decile, 1983-2007

Thousands of 2000 Dollars

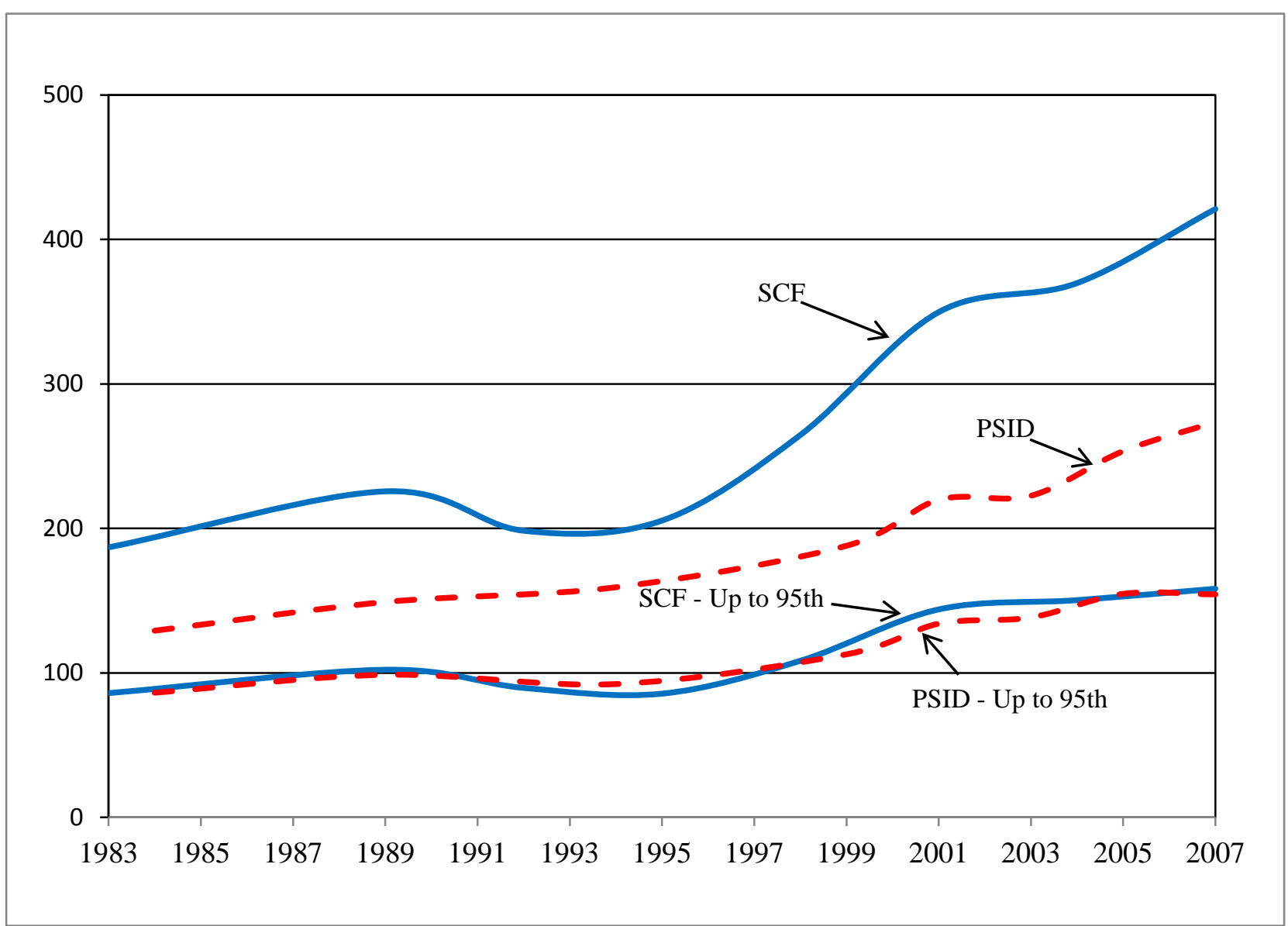

Author's calculations from the micro data files of the Survey of Consumer Finances and the Panel Study of Income Dynamics. 
Figure 2. Indexes of Home Price Change, 1985-2009

Index, $1992=1.00$

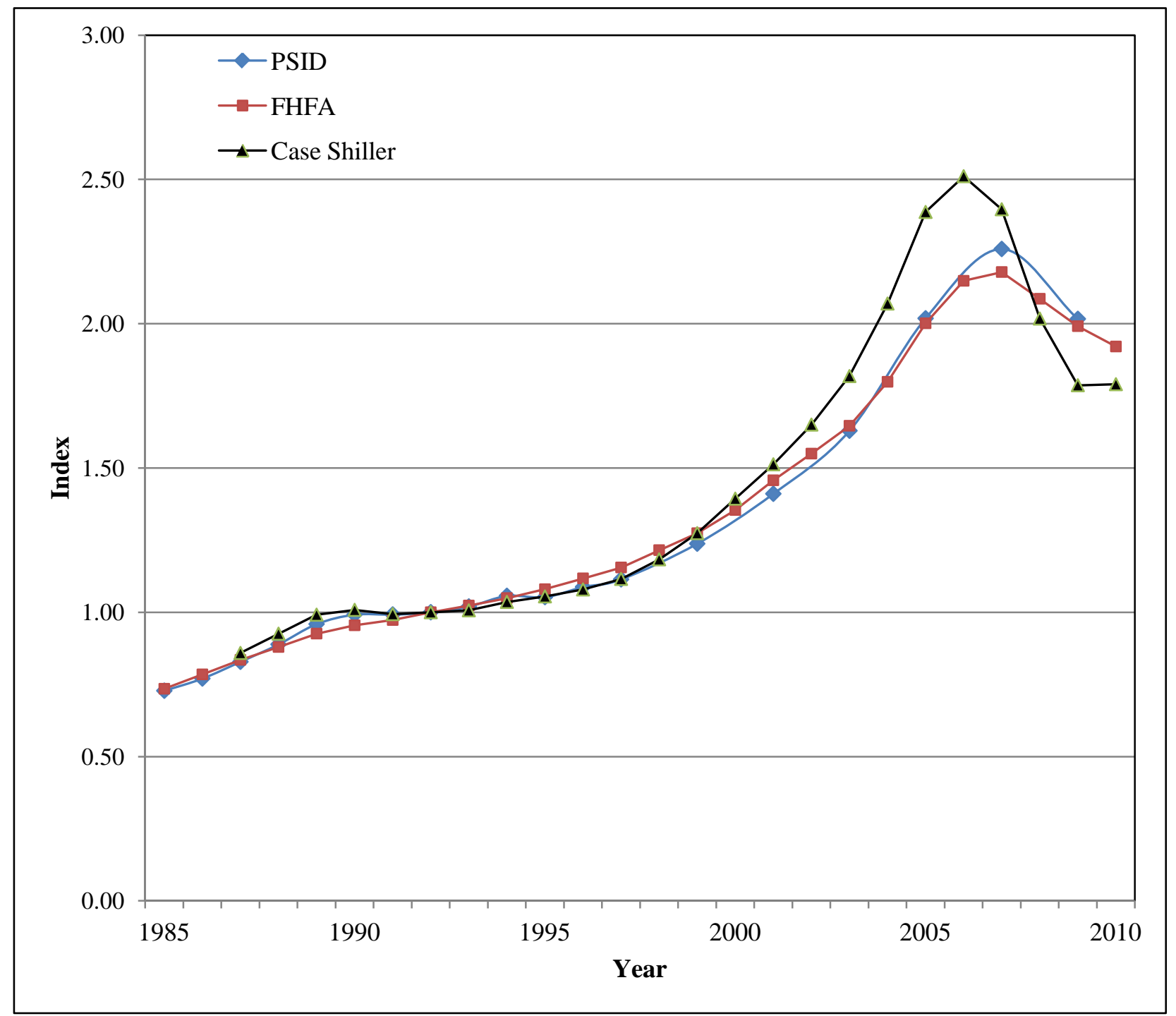

Sources: Federal Housing Finance Agency, Standard and Poors, and the Panel Study of Income Dynamics. The PSID estimates are estimated as the percent change in the mean home price of households who owned their home and did not move between two adjacent survey waves. 
Figure 3. Labor Force Participation Rates, Age 55-69, 1980-2011

Percent
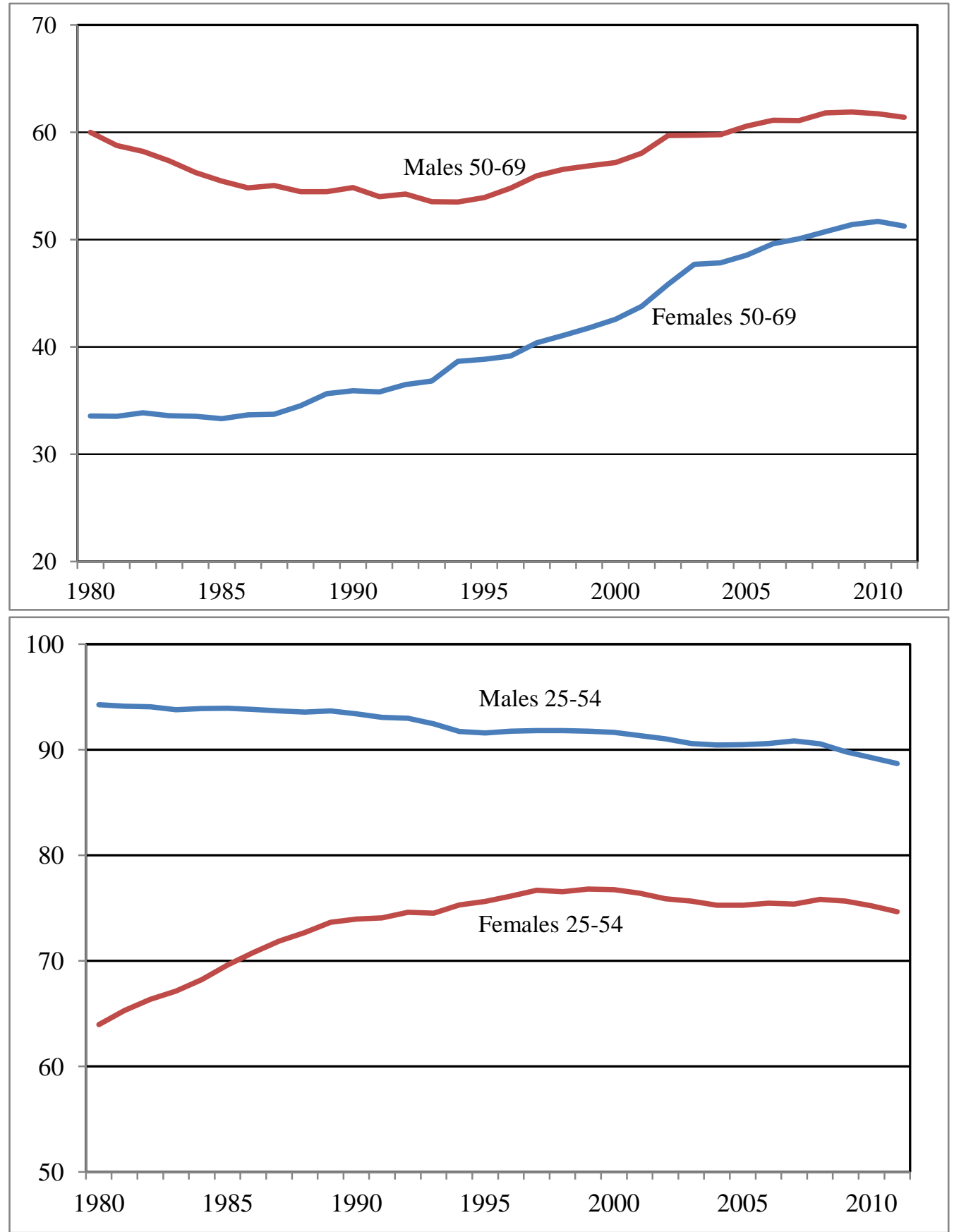

Source: Bureau of Labor Statistics and author's calculations. 


\section{RECENT WORKING PAPERS FROM THE CENTER FOR RETIREMENT RESEARCH AT BOSTON COLLEGE}

The Changing Causes and Consequences of Not Working Before Age 62 Barbara A. Butrica and Nadia Karamcheva, February 2012

The Impact of Temporary Assistance Programs on Disability Rolls and Re-Employment Stephan Lindner and Austin Nichols, January 2012

Understanding the Growth in Federal Disability Programs: Who Are the Marginal Beneficiaries, and How Much Do They Cost?

Adele Kirk, January 2012

What Explains State Variation in SSDI Application Rates?

Norma B. Coe, Kelly Haverstick, Alicia H. Munnell, Anthony Webb, December 2011

How Do Subjective Mortality Beliefs Affect the Value of Social Security and the Optimal Claiming Age?

Wei Sun and Anthony Webb, November 2011

How Does the Personal Income Tax Affect the Progressivity of OASI Benefits?

Norma B. Coe, Zhenya Karamcheva, Richard Kopcke, Alicia H. Munnell, November 2011

The Pension Protection Act of 2006 and Diversification of Employer Stock in Defined Contribution Plans

Gary V. Engelhardt, November 2011

Prescription Drug Insurance Coverage, Drug Utilization, and Cost-Related NonAdherence: Evidence from the Medicare Part D Expansion

Gary V. Engelhardt, November 2011

Social Security on Auto-Pilot: International Experience with Automatic Stabilizer Mechanisms

Barry Bosworth and R. Kent Weaver, November 2011

The Impact of Unemployment Insurance Extensions on Disability Insurance Application and Allowance Rates

Matthew S. Rutledge, October 2011

All working papers are available on the Center for Retirement Research website (http://crr.bc.edu) and can be requested by e-mail (crr@bc.edu) or phone (617-552-1762). 